\title{
Editorial
}

\section{Patron Message}

\author{
Vikram Bhojia ${ }^{1}$ \\ ${ }^{1}$ Bhojia Dental College and Hospital, Himachal Pradesh, India \\ Dent J Adv Stud 2018;6:1-2.
}

We are pleased to inform that Bhojia Dental College and Hospital has partnered with Thieme Medical and Scientific Publishers (www.thieme.com) to publish Dental Journal of Advance Studies (DJAS). From 2018 onward, the journal will be available digitally at www.thieme.com/djas with a new look and feel in print. I would like to thank the Editor-in-Chief Dr. Ajay Chhabra and the Co-Editor Dr. Varun Jindal for taking the journal forward. The journal will publish articles from all fields of dentistry with a focus in publishing original research articles and reviews. As the journal is now being published by a globally reputed publishing house, the scrutiny and selection of the content will be strictly based not only on the overall merit but also on the fact that how the presented content is addressing the progressing knowledge in dentistry. The authors are encouraged to submit their articles at http://manuscriptmanager.net/djas. While submitting, they need to strictly adhere to the International Committee of Medical Journal Editors (ICMJE) guidelines and ensure that their content is free of plagiarism. Plagiarized content will lead to immediate rejection of the article and the author might be barred from making further submissions to the journal.

Let us all come together to take the journal to the next level where the journal will be known not only in India but also overseas. To achieve the same, the editorial board of the journal and the university would like to encourage reviewers to be proactive in evaluation of the content and the authors to submit the best possible content. The DJAS team ensures that its readers engage in issues that will enhance their understanding of the investigations in dentistry and we are hopeful that in the upcoming years, the journal will scale new heights of global recognition.
Address for correspondence:

Vikram Bhojia, Bhojia Dental College and Hospital, Himachal Pradesh 173205, India

(e-mail: bhojiavikram.edu@gmail.com).
DOI https://doi.org/

10.1055/s-0038-1673730. ISSN 2321-1482.
(C)2018 Bhojia Dental College and Hospital affiliated to Himachal Pradesh University
License terms

() (1) $\ominus \circledast$ 